\title{
The 22 February 2018 landslide mechanism in Pasir Panjang Village, Brebes Regency, Central Java, Indonesia
}

\author{
Adam Raka Ekasara ${ }^{1}$, Wahyu Wilopo ${ }^{* 1,2}$, Hendy Setiawan ${ }^{1,2}$, and Dwikorita Karnawati ${ }^{3}$ \\ ${ }^{1}$ Department of Geological Engineering, Faculty of Engineering, Universitas Gadjah Mada, Yogyakarta, Indonesia \\ ${ }^{2}$ Center for Disaster Mitigation and Technological Innovation (GAMA-InaTEK) Universitas Gadjah Mada, \\ Yogyakarta, Indonesia \\ ${ }^{3}$ Indonesian Meteorological, Climatological and Geophysical Agency (BMKG), Jakarta, Indonesia
}

\begin{abstract}
On 22 February 2018 landslide occurred in Pasir Panjang Village, Salem District, Brebes Regency of Central Java Province, Indonesia. About 8 people were died, 4 people were injured and several infrastructures were damaged due to this landslide. This research is carried out to understand geological-geotechnical condition and to study the initiation mechanism of the landslide. Field investigation and UAV mapping are carried out to detect slip surface and define slope geometry. The rainfall-induced pore-water pressure is estimated by using the Slope Infiltration Distributed Equilibrium (SLIDE) model. Then, limit equilibrium method is used to estimate the safety factor of the slope, while the shear strength parameters are determined by applying back analysis approach that compared with data from laboratory tests. The results show that landslide occurred in permeable layer of silty sand overlaid above impermeable andesitic breccia. Results from back analysis indicate that the shear strength parameters and rainfall intensity are strongly influence the stability of slope against landslide.
\end{abstract}

Keywords: Landslide · Shear strength parameters · SLIDE model · Back analysis.

\section{INTRODUCTION}

On 22 February 2018, around 08:45 local time, a landslide occured at Pasir Panjang Village, Salem District, Brebes Regency of Central Java Province. Eight people reported dead, four people injured, provincial road with a length of 507 meters destroyed, one bridge cut off, and 225 meters of village road and 8.5 hectares of paddy fields buried with landslides material (PVMBG, 2018). This region is located in Bogor-Serayu Utara-Kendeng Anticlinorium zone (van Bemmelen, 1949). The area consists of steep undulating and isolated hills, undulating low hills and plains. These hills generally extend to the northwest-southeast direction. Based on regional geology, Pasir Panjang village lies

${ }^{*}$ Corresponding author: W. WILOPO, Department of Geological Engineering, Universitas Gadjah Mada. Jl. Grafika 2 Yogyakarta, Indonesia. E-mail: wilopo_w@ugm.ac.id on Tapak Formation and Kumbang Formation. Tapak Formation (Early-Middle Pliocene) consists of greenish grey coarse-grained grading upwards into finer greenish grey sandstone with some grey to yellowish sandy marl intercalations. Meanwhile, Kumbang Formation (Late Miocene-Early Pliocene) consists of andesitic to basaltic volcanic breccia, lava flows, dykes, tuf, tuffaceous sandstone and conglomerate (Kastowo \& Suwarna, 1996). With these geological and slope conditions, the study area is categorized in the high zone of susceptibility of landslide (Kadarsetia, 2011). PVMBG (2018) confirmed that rainfall and geological condition are the main factor causing this landslide. Nevertheless, investigation and research about the mechanism of landslide in Pasir Panjang Village is still few. The objective of this paper is to: (i) understand geological-geotechnical condition of landslide area and (ii) study the initiation mechanism of landslide in Pasir Pan- 
jang Village. The study area is located in Pasir Panjang Village, Salem District, Brebes Regency, Central Java with coordinates of 255608-257145 $\mathrm{mE}$ and 9212601-9210976 $\mathrm{mN}$ (Figure 1).

\section{Research Methodology}

There are several ways to analyze initiation of landslide mechanism, such as through mathematical equilibrium method, laboratory tests and or satellite remote sensing (Montarasio and Valentino, 2008; Liao et al., 2010; and Loi et al., 2017). Research of landslide in Pasir Panjang Village was conducted in several stages started from problem formulation, literature study and secondary data gathering. Secondary data consist of DEMNAS satelite imagery, rainfall intensity, and regional geological map. The second stage includes UAV mapping, geological mapping, groundwater observation, soil and rock sampling, and laboratory analysis (Figure 2). UAV mapping with DJI Phantom 4 PRO was carried out to generate Digital Surface Model (DSM) for post-landslide topography. Three undisturbed soil samples (UDS) and two disturbed samples (DS) that represent the unstable zone and the headscarp, two samples DS of depositional zone, and two samples of bedrock were taken for laboratory tests. Laboratory tests were conducted to obtain engineering parameters including water content, specific gravity, Atterberg limits, grain-size, permeability and shear strength. The shear strength parameters for rocks are obtained by combining the Geological Strength Index (GSI) values (Hoek and Brown, 1997) with the point load test to get Hoek Brown parameter. The conversion of Hoek Brown parameters into the MohrCoulomb parameters are carried out using Rocdata software.

Analysis of geomorphology and geology were carried out to reconstruct the slope model. Morphology before and after the occurrence of landslide are compared by using remote sensing with the observations on the field. The rainfall-induced pore-water pressures were estimated by using the Slope Infiltration Distributed Equilibrium (SLIDE) model. The SLIDE model simplifies calculation of pore water pressure that generated from rainfall intensity. Rainfall data is taken from weather station at Malahayu provided by Meteorology, Climatology, and Geophysical Agency (BMKG). According to Liao et al. (2010) pore pressure acting on the sliding surface can be expressed by Equation 1:

$$
\Delta U=m \cdot H \cdot \gamma_{n} \cdot \cos ^{2} \beta
$$

and change in the ratio of groundwater layer to the soil layer pressure $(m)$ is calculated by Equation 2:

$$
\begin{aligned}
& m_{1}=0 \\
& O_{t}=K_{t} \cdot \sin \beta \cdot m_{t} \cdot H \cdot \cos \beta \cdot \Delta t \\
& \Delta m_{t}=\frac{I_{t}-O_{t}}{n \cdot H \cdot\left(1-S_{r}\right)} \\
& m_{t+1}=m_{t}+\Delta m_{t}
\end{aligned}
$$

Where $t$ is time, $\Delta t$ is time interval, $m_{1}$ is initial value of $m$, and $m_{t}$ is calculated at each time-step. $O_{t}$ represents the water outlet of a finite portiont of a slope of finite length $L$. $I_{t}$ is rainfall intensity, and $K_{t}$ is the significance of a global drainage capability due to both the intrinsic soil permeability and the presence of numerous preferential down-flow ways. The SLIDE model is a simplistic model that neglects certain effect such as transpiration from trees and vegetation, and the initial unsaturated infiltration process, but provides an appropriate model for use in computer simulation (Loi et al., 2017).

Back analysis is used to determine the shear strength parameters at critical condition (Tang et al., 1999; Berti et al., 2017; Calcatera and Santo, 2004; Urgeles et al., 2004). Back analyses in the case of Pasir Panjang landslide is performed by using limit equilibrium Bishop method implemented in SLIDE 7.0 by Rocscience. Circular slip surfaces in the model are considered to account for failure mechanism. Failure plain for this case is assumed from result of morphology analysis.

Slope stability analysis is aim to obtain value of factor safety. The factor safety is defined as the ratio of resisting shear strength to driving shear stress. For failure slope, Bowles (1991) defines that the factor of safety is lower than 1,07 . Factor of safety was calculated using the following Equation 3: 


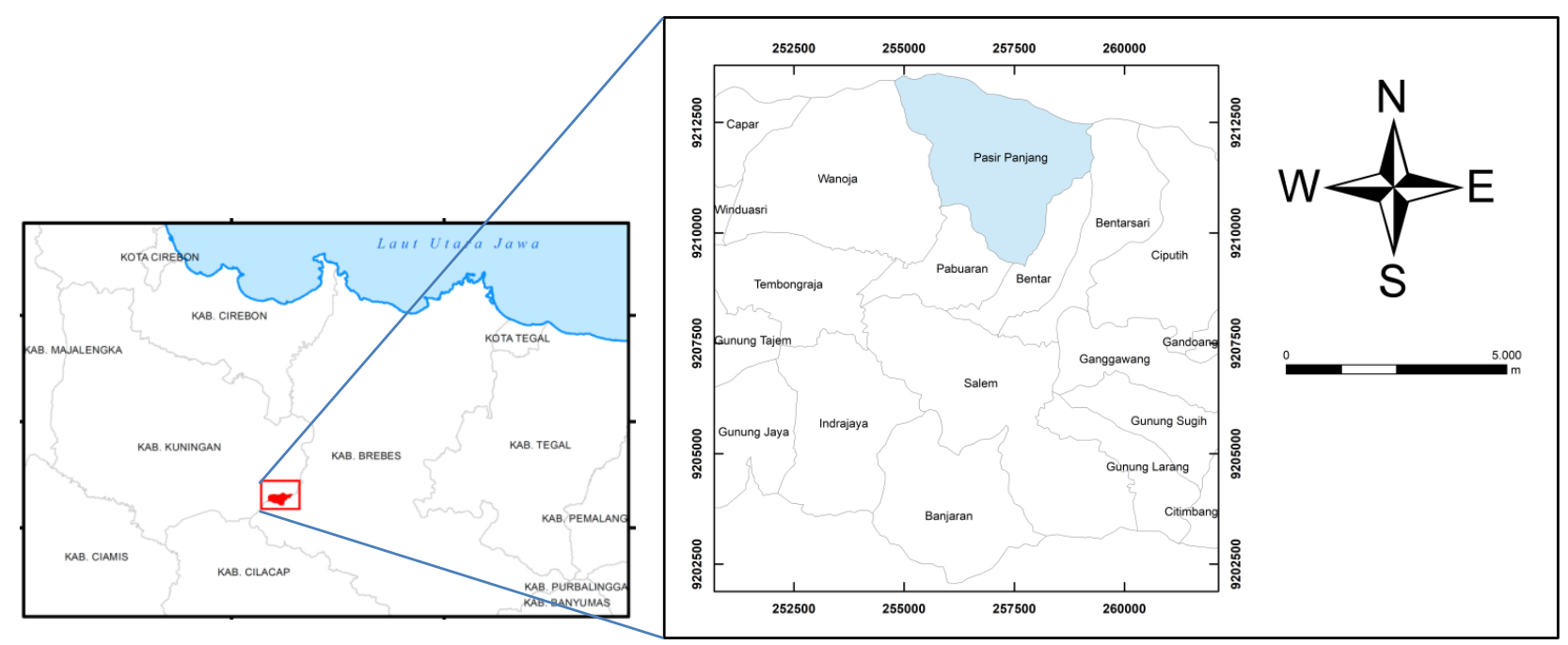

Figure 1: Study area.
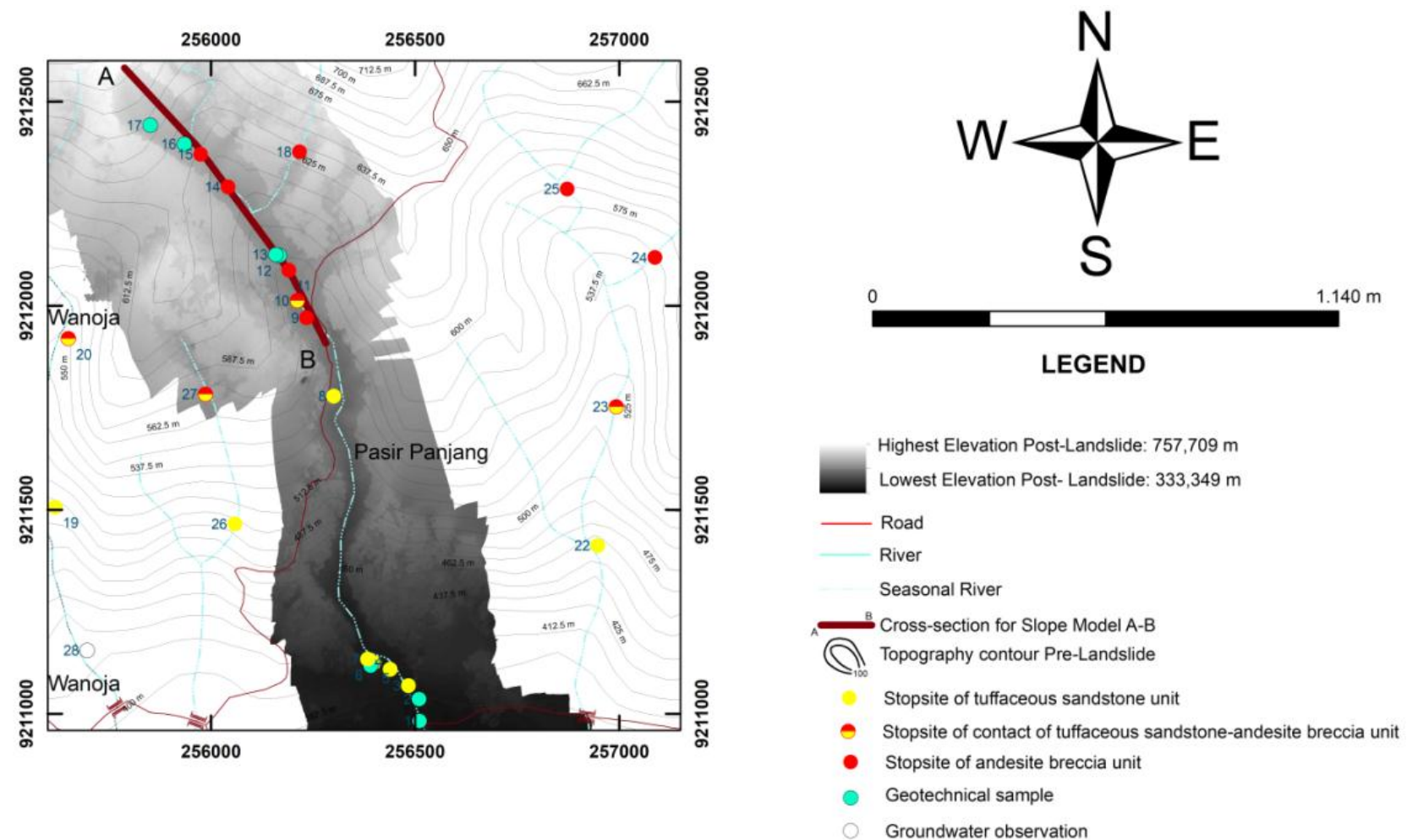

Figure 2: Stopsite map. 


$$
F=\frac{\sum_{i=1}^{n}\left[c^{\prime} b_{i}+W_{i}\left(1-r_{u}\right) \tan \varphi^{\prime}\right]\left(\frac{1}{\cos \theta_{i}\left(1+\frac{\tan \theta_{1} \tan \varphi^{\prime}}{F}\right)}\right)}{\sum_{i=1}^{n} W_{i} \sin \theta_{i}}
$$

Where $c^{\prime}$ is effective cohesion, $b_{i}$ is horizontal length of the $i$-th slice $(\mathrm{m}), W_{i}$ is the weigth of the $i$-th slice, $r_{u}$ is ratio of pore water pressure, $\varphi^{\prime}$ is effective internal friction angle.

\section{Results AND Discussion}

\subsection{Geomorphological analysis}

Morphology before landslide is obtained from DEMNAS imagery data with resolution size of $8.1 \mathrm{~m}$. It shows that the study area has 320 meters to 740 meters of height with a slope ranged from $23^{\circ}$ in high to $6^{\circ}$ in lower regions (Figure 3a). Morphology after landslide is derived from UAV data with resolution size of $1 \mathrm{~m}$. The study area after landslide has 320 meters to 760 meters of height with a slope ranged from $49^{\circ}$ in high to $7^{\circ}$ in lower regions (Figure $3 b$ ).

The combination of morphology before and after the landslide event can be seen in Figure 3, where the lowering elevation ranged around $0-50 \mathrm{~m}$ are exist particularly in the main location of landslide. The ground movement is generally elongated towards the Northwest Southeast direction then relatively moving to the South. According to field observations, the maximum depth of slip surface is of $26 \mathrm{~m}$ from the surface (Figure 4).

\subsection{Geological and geotechnical condition}

From geological mapping, the study area is divided into 2 geological units. The youngest unit is tuffaceous sandstone and the oldest unit is andesitic breccia. In this study are, the geological structure is shear joint. The geological map of study area is shown in Figure 5.

Based on field investigation and laboratory analysis, the study area is divided into 2 geotechnical units, i.e., silty sand unit and andesitic breccia unit. Silty sand interpreted as result of weathering of tuffaceous sandstone. Silty sand has engineering properties such as water content around $47.94-55.16 \%$, spesific gravity of 2.69-2.76, plastic limit around 29.8637.38, liquid limit of 45.37-54.95, plastisity index around 9.43-18.24, unit weight around $17.65-18.82 \mathrm{kN} / \mathrm{m}^{3}$, permeability around 1.93 $\times 10^{-2}-2.06 \times 10^{-2} \mathrm{~m} / \mathrm{s}$, porosity around $49.25-55.37 \%$, saturation degree around 79.51$90.95 \%$, cohesion around 9.61-20.88 $\mathrm{kPa}$ and internal friction angle of $29.8^{\circ}$. While andesitic breccia has unit weight of $24.51 \mathrm{kN} / \mathrm{m}^{3}$ and point load test result of $1.2 \mathrm{MPa}$, Geological Strength Index is 60, and $m_{i}$ assumed at 19 . According convertion to the Mohr-Coulomb criteria, this unit have the cohesion of $84 \mathrm{kPa}$ and the internal friction angle of $39^{\circ}$.

\subsection{Slope model}

The slope model is constructed based on geotechnical properties and comparation of morphology pre-landslide with post-landslide. The upper layer is composed by silty sand and the lower layer is composed by andesite breccia. A firm blue line illustrates the surface boundary before a landslide occured from the DEMNAS data. The dotted blue line describes the surface boundary after a landslide was taken from the UAV data (Figure 6).

In this study, the slip surface is assumed as a complex type. The first one is rotational landslide movement, which is characterized by a curved plane as initiation mechanism. The second one is extention of landslide triggered debris flow by the presence of river water flow.

\subsection{Back Analysis}

In the first case, the calculation for $0 \mathrm{~m}$ of groundwater depth resulting the cohesion from $0-2,8-12,18-20 \mathrm{kPa}$ (in step of $2 \mathrm{kPa}$ ) for samples, the internal friction angle varies from 0 $4,12-16,24-28$ degrees (in step of 2 degrees) for samples. The calculation of factor of safety is then continued for variations in depth of 1 $\mathrm{m}$ and $2 \mathrm{~m}$ for variations in soil shear strength at the same interval as the previous calculation (Figure 7).

The analysis results show a strong correlation between groundwater level (Figure 8 and 

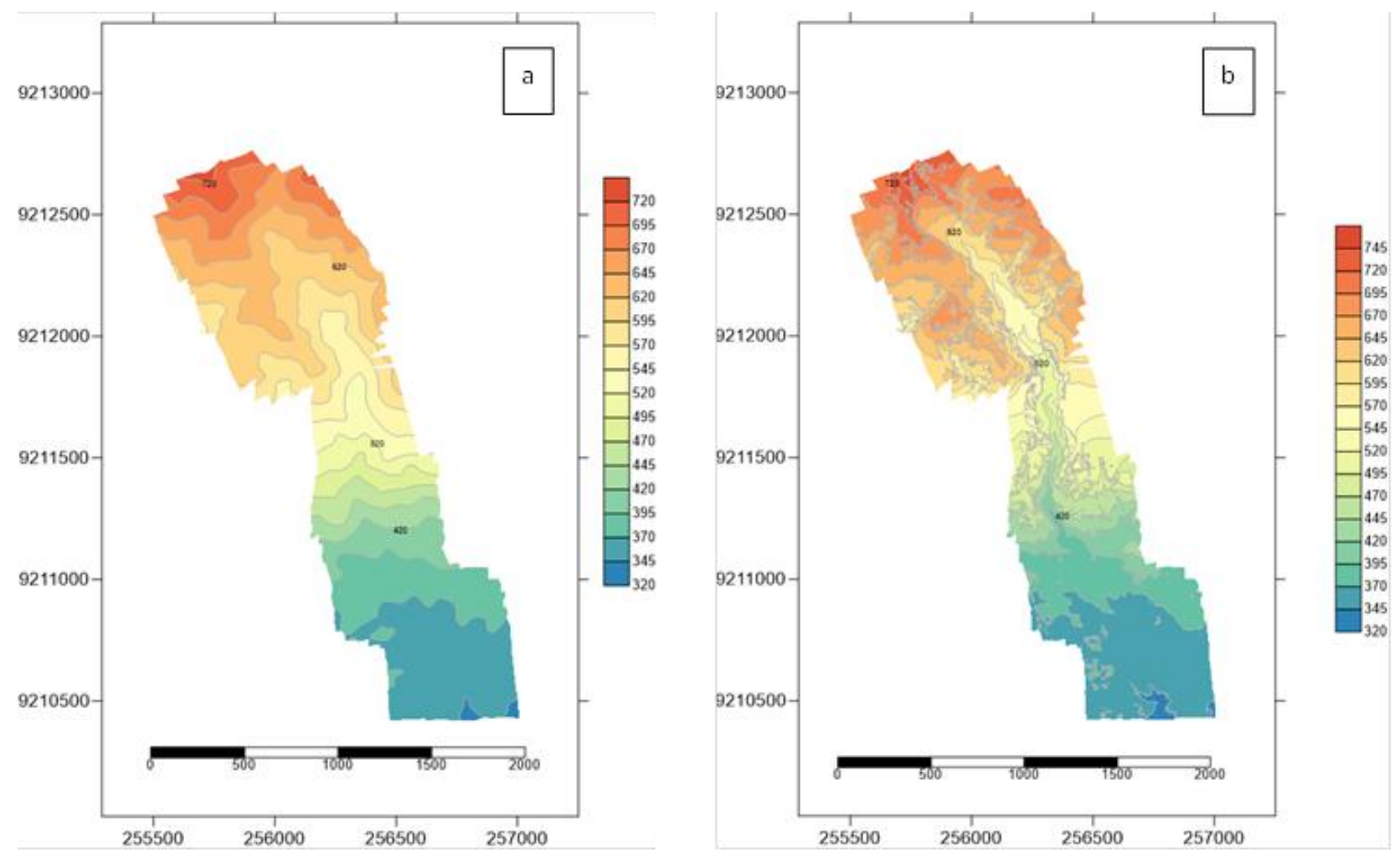

Figure 3: (a) Contour of pre-landslide and (b) post-landslide.

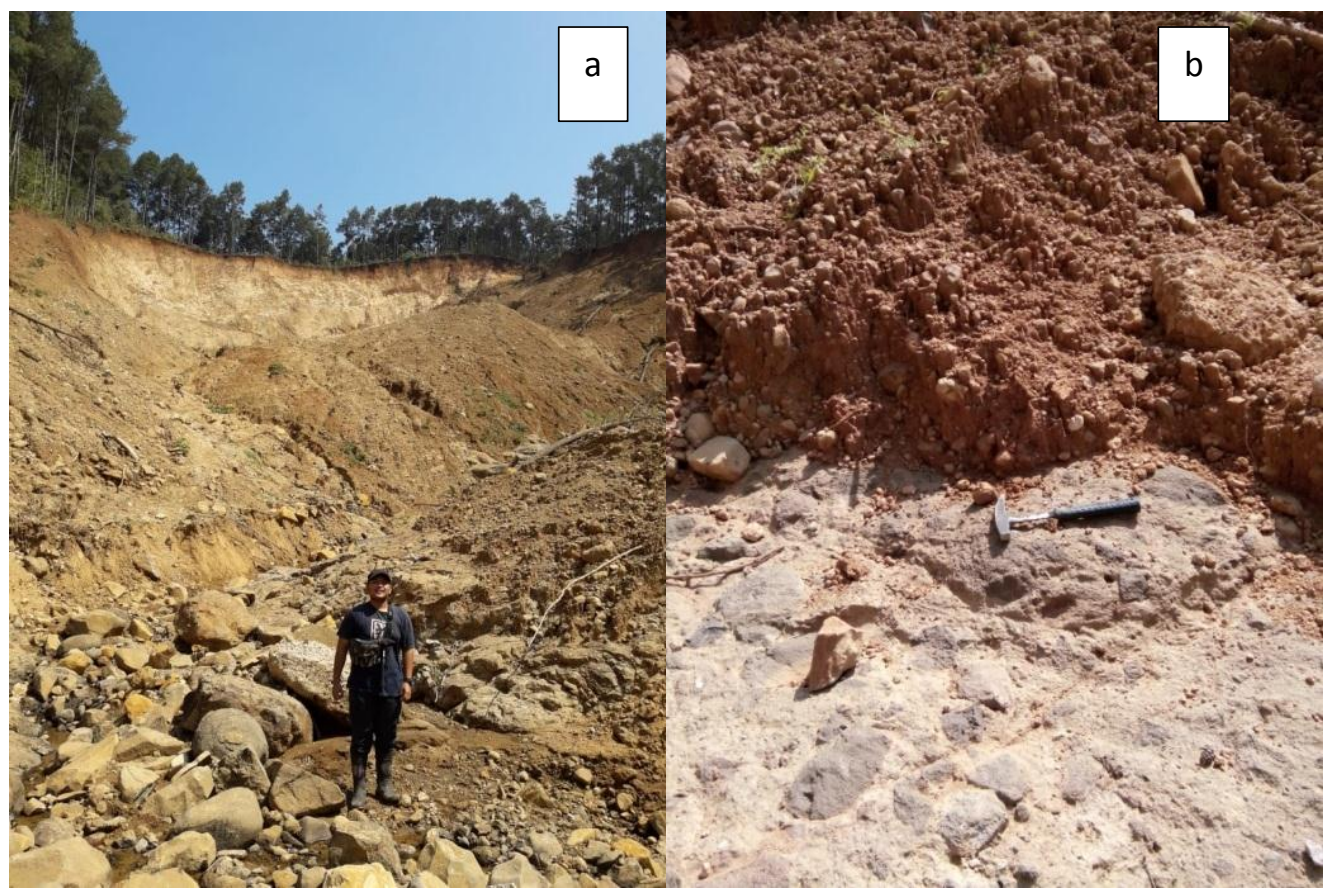

Figure 4: (a) Crown of landslide and (b) Slip surface of landslide. 


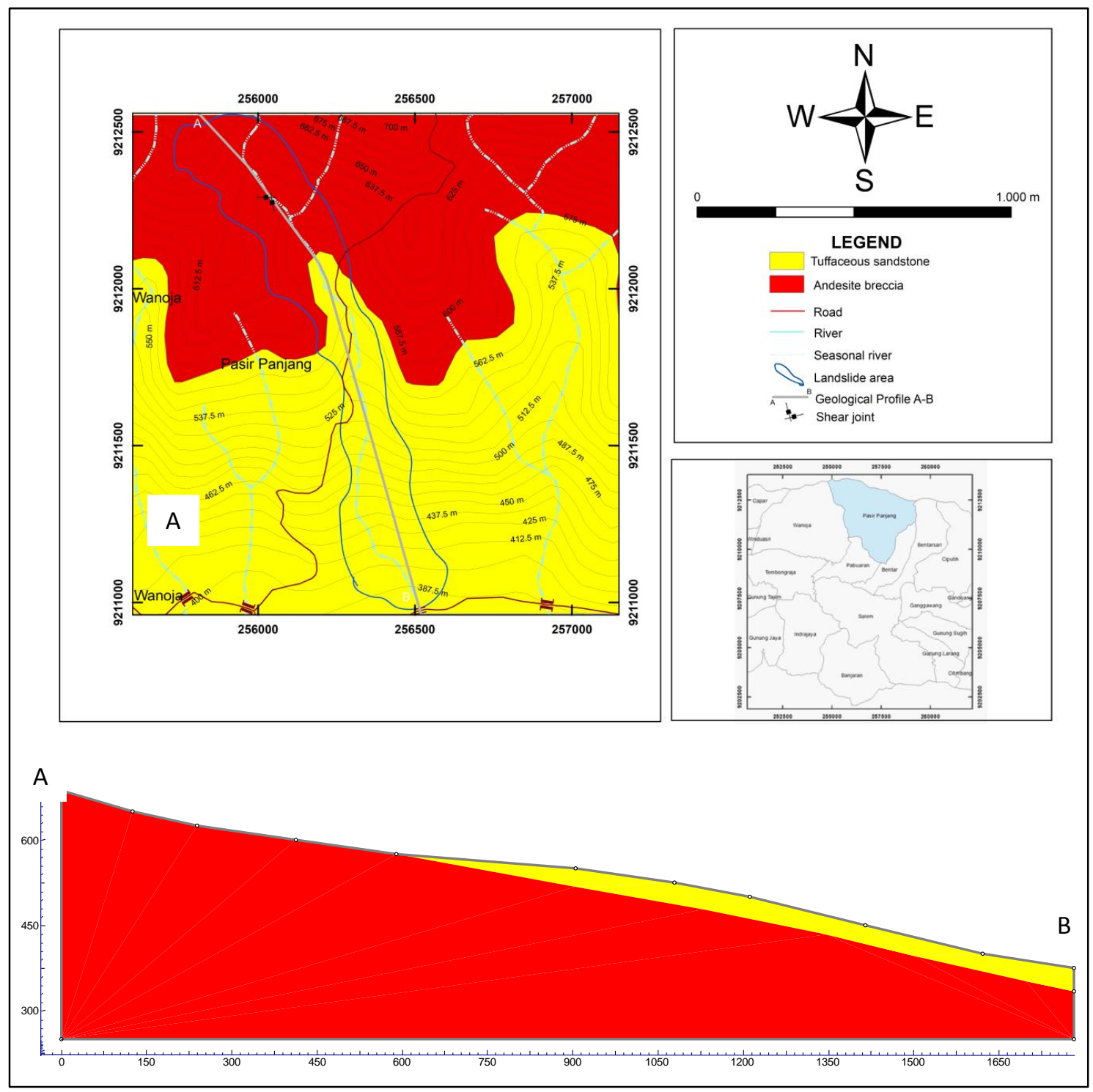

Figure 5: Geological map of study area.

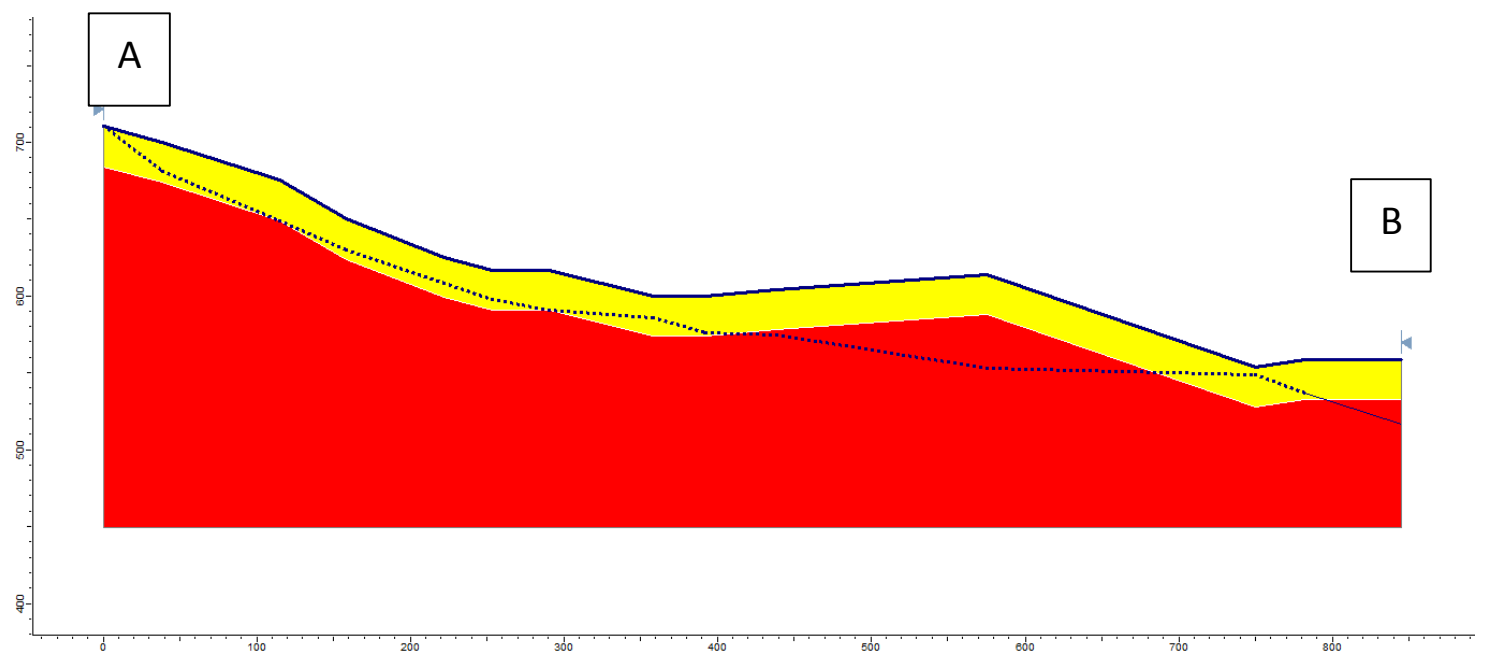

Figure 6: Slope geometry model. 

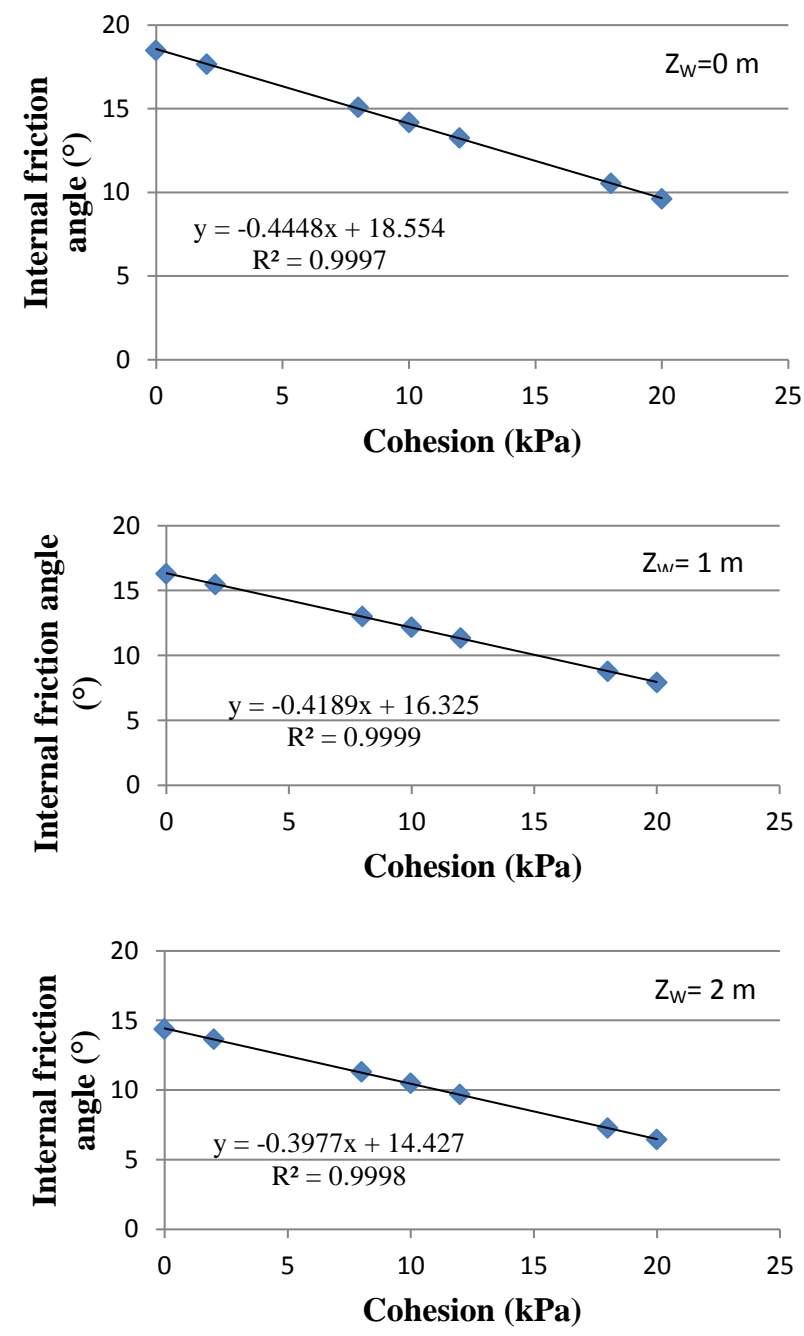

Figure 7: Relationship between cohesion and internal friction angle which generates $\mathrm{SF}=1.06$ for $0-2 \mathrm{~m}$ groundwater depth.

Figure 9), cohesion and internal friction angle which give the factor of safety of 1.07. At a depth of more than $9 \mathrm{~m}$ the calculation results show the internal friction angle in negative value, considering that this case is ignored. Correlation relationships can be expressed in Equation 4. The equation is valid if and only if the value of $\varphi \geq 0, c \geq 0,0 \leq Z_{w}<9$.

$\varphi=\left(-2.0635 Z_{w}+18.499\right) c+0.0235 Z_{w}-0.444$

The next step is synthesize the results obtained from field observations, laboratory tests, empirical correlations and the results of back analysis. On 25 August 2018 we found a spring with a depth of $6 \mathrm{~m}$ from the surface, while based on calculations using the SLIDE ap-

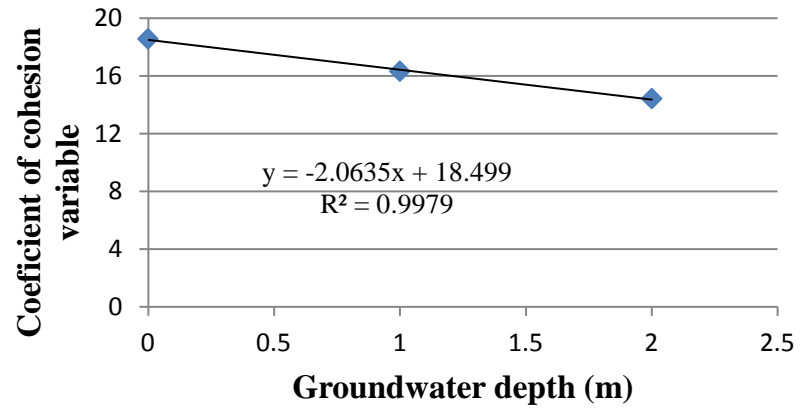

Figure 8: Relationship between groundwater depth with coeficient of cohesion variable.

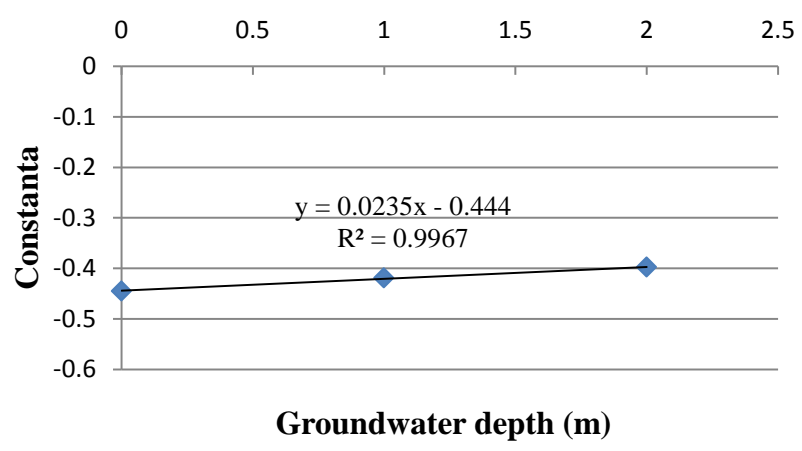

Figure 9: Relationship between groundwater depth with constanta.

proach, from 13 February 2018 until 22 February 2018, the increase of groundwater level of $4.63 \mathrm{~m}$ (Figure 10), so that if there is no change in the increase of groundwater level before the time when landslide occur, the groundwater level is estimated to be at a depth of $1.37 \mathrm{~m}$. If it was assumed that February is the peak of the occurrence of rain and there has been a groundwater fluctuation of $0.37 \mathrm{~m}$ in November-January, then in the next analysis it is assumed that when the initial landslide occur, the groundwater table was at a depth of $1 \mathrm{~m}$. If combined with the SLIDE approach, groundwater fluctuations are obtained for further analysis.

\subsection{Landslide mechanism}

The results of the simulations for landslide in Pasir Panjang Village are shown in Figure 11. On February 13, 2018 when the day is not rain, the groundwater level is at a depth of $5.64 \mathrm{~m}$ which results in a near stable slope with a safety factor worth at 1.212. On February 15-16, 2018 rainfall came with intensity of $28-45 \mathrm{~mm}$ which resulted in an increase of groundwater level to 


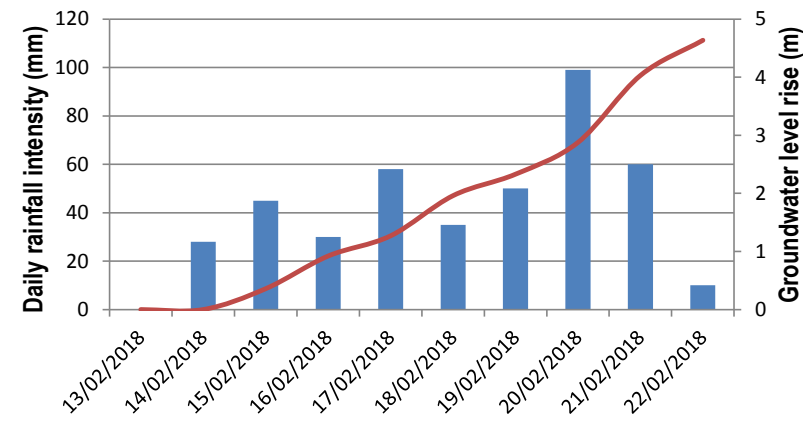

Figure 10: Daily rainfall intensity and groundwater level rise from 13 February 2018 until 22 February 2018.

a depth of $4.71 \mathrm{~m}$ which cause the slope in a critical condition with a safety factor of 1.183 . On February 18-20, 2018 the rainfall continues to increase and reach to its peak on February 21, 2018 at $90 \mathrm{~mm}$. On February 22, rainfall began to decrease to $60 \mathrm{~mm}$, but the groundwater level increase continuously until it reaches a depth of $1 \mathrm{~m}$, resulting the beginning of landslide with a safety factor of 1.062 . The initiation of landslide is caused by the load itself from the soil mass which is supported by the presence of static stress due to an increase of pore water pressure.

On February 22 the soil mass moving down the slope to the river originating from the east of the landslide location. This water flow has a certain speed which results in dynamic stress. In this case static stress and dynamic stress then work on soil mass which only have the residual shear strength resulting in debris flow.

\section{CONCLUSION}

Based on the study results, geological condition of the area consists of tuffaceous sandstone unit and andesitic breccia unit. There were also a number of shear joint and springs. Geotechnically, the study area consists of silty sand unit and andesitic breccia unit. Silty sand unit is interpreted as a result of weathering of andesitic breccia and tuffaceous sandstones which have moderate to high plasticity, low to moderate permeability. While andesitic breccia units tend to be impermeable and have very high shear strength.

Landslide occured among permeable silty sand material with low shear strength, while the slip surface of andesitic breccia has high shear strength and also impermeable. The high intensity of rainfall ( $209 \mathrm{~mm}$ for 3 days) results in an increase of the ground water level and pore water pressure which triggers the initial movement of landslide. Furthermore, the flow of water at a certain speed acts as a dynamic stress on the moving soil mass which triggers the occurrence of debris flow.

\section{ACKNOWLEDGEMENTS}

The authors would like to thanks to Tahir Foundation and Geological Engineering Department UGM for supporting all expense in this research. We also thanks to assistant in the Laboratory of Environmental Geology UGM for helpful discussions and their support in the field.

\section{REFERENCES}

Berti, M., Bertello, L., Bernardi, A., Caputo, G. (2017) Back analysis of a large landslide ina flysch rock mass. Landslide 14, 2041-2058.

Calcatera, D. \& Santo, A. (2004) The January 10, 1997 Pozzano landslide, Sorrento Peninsula, Italy. Engineering Geology 75, 181-200.

Hoek, E. \& Brown, E. (1997) Technical Note Practical Estimates of Rock Mass Strength. lsevier: International Journal Rock Mechanics and Mining Sciences Vol 34, 1165-1186.

Kadarsetia, E. (2011) Zonasi kerentanan Gerakan Tanah di Kabupaten Brebes bagian Selatan, Provinsi Jawa Tengah. Buletin Vulkanologi dan Bencana Geologi Vol. 6 No.1, 39-51 (in Indonesian language)

Kastowo \& Suwarna, N. (1996) Geological Map of The Majenang Quadrangle, Jawa. Bandung: Geological Research and Development Center.

Liao, Z., Hong, Y., Wang, J., Fukuoka, H., Sassa, K., Karnawati, D., Fathani, T. (2010) Prototyping an experimental early warning system for rainfallinduced landslides in Indonesia using satellite remote sensing and geospatial datasets. Landslides 7, 317-324.

Loi, D., Quang, L., Sassa, K., Takara, K., Dang, K., Thanh, N., Thien, P. (2017) The 28 July 2015 rapid landslide at Ha Long City, Quang Ninh, Vietnam. Landslides 14, 1207-1215.

Montarasio, L. \& Valentino, R. (2008) A model for triggering mechanisms of shallow landslides. Nat. Hazard. Earth Science 8, 1149-1159.

PVMBG (2018, Februari 26) Laporan Sementara Pemeriksaan Gerakan Tanah Di Desa Pasirpanjang, Kecamatan Salem, Kabupaten Brebes, Provinsi Jawa Tengah. Dipetik April 19, 2018, dari Pusat Vulkanologi dan Mitigasi Bencana Geologi-Badan Ge- 


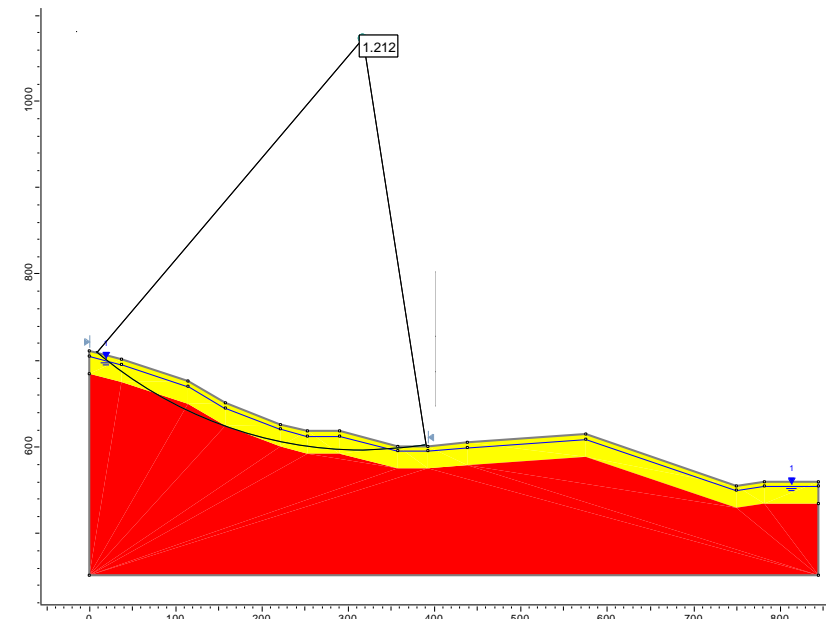

a) 14 February $2018: Z_{w}=5.64 \mathrm{~m}$, $\mathrm{SF}=1.212$ (no rainfall)

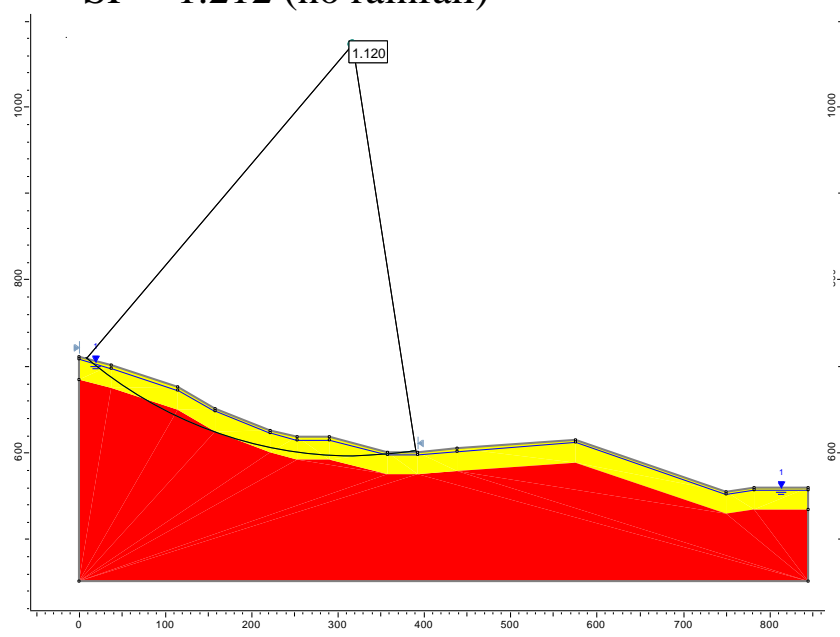

c) 20 February $2018: Z_{\mathrm{w}}=2.76 \mathrm{~m}$, $\mathrm{SF}=1.120$ (critical condition)

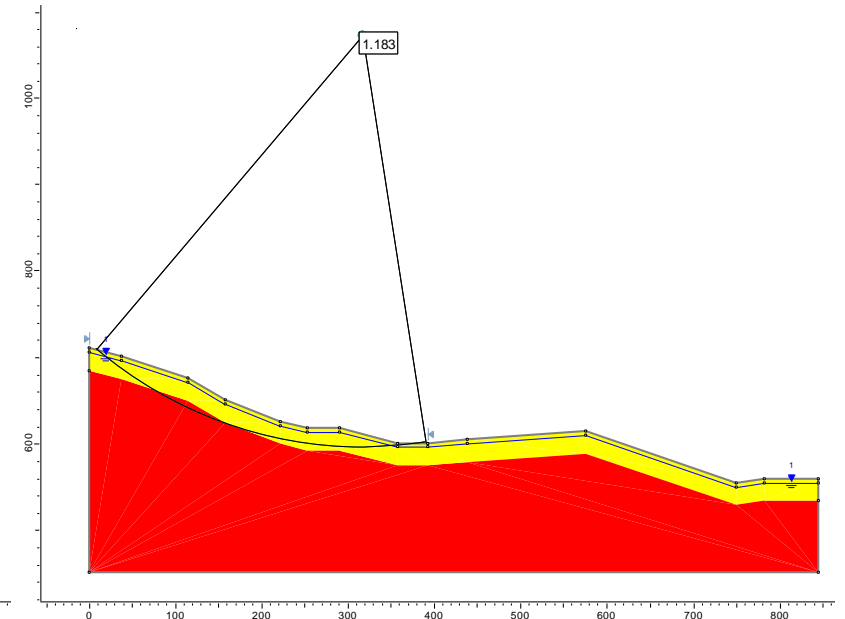

b) 16 February $2018: Z_{\mathrm{w}}=4.71 \mathrm{~m}$, $\mathrm{SF}=1.183$ (critical condition)

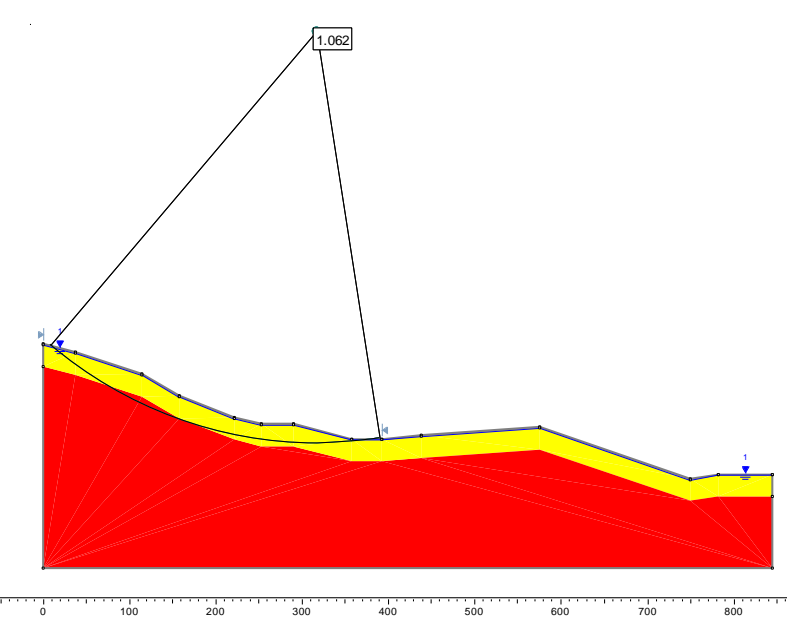

d) 22 February 2018: $Z_{w}=1 \mathrm{~m}$, $\mathrm{SF}=1.062$ (landslide occured)

Figure 11: Illustration of landslide mechanism.

ologi: http://www.vsi.esdm.go.id/ (in Indonesian language).

Tang, W., Stark, T., Angulo, M. (1999) Reliability in Back Analysis of Slope Failures. Soils and Foundations vol 39 no 5, 73-80.

Urgeles, R., Leynaud, D., Lastras, G., Canals, M., Mienert, J. (2006) Back-analysis and failure mech- anisms of a large submarine slide on the ebro slope, NW Mediterranean. Marine Geology 226, 185-206.

van Bemmelen, R. W. (1949) The Geology of Indonesia vol IA. The Hague, Netherland: Martinus Nijhof. 